NBER WORKING PAPER SERIES

\title{
DIMENSIONS AND DETERMINANTS OF EARLY \\ CHILDHOOD HEALTH AND MORTALITY \\ AMONG AMERICAN SLAVES
}

\author{
Richard H. Steckel
}

Working Paper No. 1662
NATIONAL BUREAU OF ECONOMIC RESEARCH 1050 Massachusetts Avenue
Cambridge, MA 02138
July 1985

The author has benefited from comment or discussions with Stanley Engerman, Robert Fogel, Ken Kiple, Robert Margo, J.M. Tanner, Eugene Weinberg, and workshop participants at the the University of chicago. The research reported here is part of the NBER's research program in Development of the American Economy. Any opinions expressed are those of the author and not those of the National Bureau of Economic Research. 
Dimensions and Determinants of Early Childhood Health and Mortality Among American Slaves

\section{ABSTRACT}

This paper relies on birth and death lists from plantation records to investigate the causes of low birth weight and poor health of young slave children. The sources of deprivation can be traced to the fetal period. The slave work routine was arduous overall and particularily intense during planting, hoeing, and harvesting. These demands combined with seasonal fluctuations in disease and in the quality of the diet implied that few newborns had escaped stress on intrauterine growth. Starchy food supplements given soon after birth and poor sanitation surrounding feeding provided a poor environment for growth during the first year of life.

Richard H. Steckel Economics Department Ohio State University Columbus, Ohio 43210 (614) 422-5008 


\section{INTRODUCTION}

The antebellum campaign against slavery was filled with emotional rhetoric. Although the competing claims and counter-claims of abolitionists and pro-slavery writers tell us little about the actual nature of slavery, the debate defined issues that are important to modern research on slavery. Among these issues are the material conditions of slave life, the work or physical exertion required of slaves, and the care given to children and to pregnant women.

Traditional sources such as plantation records, medical journals, census materials, diaries, and interviews of ex-slaves have been brought to bear on questions raised by the antebellum debate (Phillips, 1918; Stampp, 1956; Fogel and Engerman, 1974; Genovese, 1974; Sutch, 1975, 1976; Owens, 1976; Kiple and Kiple, 1977; Savitt, 1978; Crawford, 1980; Campbe11, 1984). More recently height data have been added as grist for the analytical mill that involves the health and nutrition of populations (Stecke1, 1979a; Sandberg and Stecke1, 1980; Eltis, 1982; Fogel, Engerman, and Trusse11, 1982; Floud and Wachter, 1982; Sokoloff and Villaflor, 1982; Friedman 1982; Margo and Stecke1, 1982; Stecke1, 1983; Margo and Stecke1, 1983; Fogel et al., 1983; Higman, 1984). Previous work utilizing height data in connection with the health of American slaves has stressed patterns among adolescents and adults (Steckel, 1979a; Margo and Steckel, 1982). Yet it is clear from the literature on human growth that average heights of children are an excellent index of health (Tanner, 1962, 1978; 1981; Eveleth and Tanner, 1976). This paper examines the nutrition and mortality of young slave children using height data from coastwise manifests and mortality data from plantation records. 1 The height and mortality data suggest that the health of slave children was comparable 
to that among the poorest populations in developing countries of the midtwentieth century. The paper traces the origins of poor health to conditions during pregnancy and during the child's first year of life.

\section{HEIGHTS OF SLAVE CHILDREN}

Table 1 gives the average height, standard deviation, sample size, and velocity of height attained by slave children aged 1-6. Age customarily refers to age at last birthday, and if the exact ages were evenly distributed over the age interval then the average age of the group that was age $n$ at last birthday would have been $n+1 / 2$. Height velocity--the change in height between successive ages- - is calculated from average age $n+1 / 2$ to average age $n+1+1 / 2$ and therefore is centered at exact age $n+1$.

The slave manifests are an extraordinary body of height data for the early nineteenth century: the observations are abundant, collection occurred over more than 5 decades, measurements are available for both sexes, and children are included. The last two features distinguish these data from most other eighteenth and early nineteenth century sources, and consequently the direct comparisons that can be made with populations contemporary with slaves are limited. For this reason and for the reason that much is known about the growth and development of modern populations, it is desirable to compare slave growth patterns with those of modern populations. 2

Table 2 compares slave with modern height standards. By scanning down the second column for each sex one can readily see that the absolute difference in heights declined with age. The difference exceeded 8 inches at age 1 and within 2 years declined to 5 to 6 inches. The fourth column under each sex gives the number of standard deviations that the difference was below the modern standard, and the fifth column converts this information into the 
centile of the modern standard under the assumption that heights are normally distributed.

If the data are taken at face value, then young slave children were extraordinarily smal1. At age one the slaves were nearly Lilliputians compared to their modern counterparts. Catch-up growth, defined as upward movement through the centiles, was rapid from age 1 to 2 and then more gradual for the next several years. Slaves did not reach the first centile of modern standards until age 5 (females only).

Any use of the slave manifests should include a dicussion of possible biases. 3 The data at ages 1 and 2 should be viewed skeptically. Most children aged 1 and some of those aged 2 could not walk or could not stand very 1ong. Although little information about actual technique is available, the measurements were probably done while the children were lying down. The real difficulty in these measurements is getting children to stretch out properly-they just don't like it. Modern techniques and modern equipment take this into account. Consequently, the heights (or lengths) of these children were probably biased downward relative to modern standards. The exceptional value of measured velocity between ages 1 and 2 is consistent with this hypothesis. The average increase in height (or length) for males and females from age 1 to 2 was about 5.58 inches, which exceeds the 97 th centile of modern velocity standards (Tanner et al., 1966, 615-616). Although conditions may have improved such that slaves experienced catch-up growth, the poor health and nutrition at these ages (discussed below) suggest that a portion of the measured velocity is an illusion attributable to the fact that a larger share of the children aged 2 were measured while standing.

According to modern height standards presented in Table 2, the standard deviation of heights for young children is in the range of 1.69 to 2.20 
inches. The standard deviations given in Table 1 are more than twice as high as the modern standards. While a portion of this phenomena may be attributable to age and height heaping, evidence discussed below suggests that there may have been considerable heterogeneity within the population of slaves.

Slave children were small compared to children among poor populations in developing countries. Table 3 compares a selection of the lowest average heights observed in developing countries to modern height standards. At age 3 slave children on average did not exceed the 0.2 centile, and the other groups in Table 3 range from 0.3 to 12.1 . Populations as poor as slum dwellers in Lagos, Nigeria and urban residents in Bangladesh provided an environment for growth superior to that faced by slave children.

\section{POSSIBLE CAUSES}

Modern studies of child growth and development may provide clues to the small stature of slave children. Human growth occurrs in two ways (Hurley, 1980; Tanner, 1978). One is an increase in the number of cells and the other is an increase in the size of cells. Initially organisms grow through proliferation of cells, then during a second phase cell proliferation slows down and cell size increases rapidly. In the third phase there is almost no cell pro1 iferation and cell size increases rapidly. If conditions are poor during the phase of rapid cell proliferation the number of cells is restricted and cannot be increased even by supplementary feeding at a later time. However, reversal of small cell size may be possible by later feeding.

Although various organs of the body have different time sequences for the various phases of growth, cell multiplication as opposed to growth in cell size is largely responsible for the high growth rate of the fetus compared to 
the child. It is thought that few, if any nerve cells and only a small proportion of new muscle cells, for example, appear more than 28 weeks after fertilization has occurred (Tanner, 1978, 39). Thus conditions in the fetal period are critical to later development.

Modern studies establish that general material malnutrition, infections, dietary deficiencies, physical exertion relative to diet, and ingestion of toxic substances during pregnancy may retard fetal and child growth (Keys et al., 1950; Hytten and Leitch, 1971; Tanner, 1978; Hurley, 1980). Evidence from war-related famines and from developing countries establish the importance of maternal nutrition. Studies of the Dutch famine in the winter of 1944-1945 show that the outcome of pregnancy is particularly sensitive to conditions in the first and last trimesters. The incidence of abortions and miscarriages, stillbirths, and malformed children rose among pregnancies exposed to famine during the first trimester only, whereas undernutrition during the last trimester alone reduced birth weight (Hurley, 1980, 77-81; Stein et al.., 1975, chaps. 10 and 12). Length of gestation was lowest among those exposed to famine during the first trimester only. However compared to those not exposed to famine the difference was only 4 days and the result cannot be attributed to nutrition (Stein et al., 1975, 105-106). The correlation between weight gain during pregnancy and birth weight of the child is higher (in absolute terms) among women who were underweight before pregnancy (Lechtig et al., 1975). Thus chronic malnutrition compounds the effects of a given environmental insult that occurs during pregnancy.

Infections diminish nutritional status by reducing appetite and by lowering nutrient absorption and utilization (Martorel1, 1980). Fetal infections, which are common in developing countries, are important causes of intrauterine 
malnutrition. Maternal $i 11$ nesses, such as respiratory and gastrointestinal infections and malaria, retard intrauterine growth (Jelliffe, 1968).

Specific dietary deficiencies may contribute to diminished growth and development (Hurley, 1980, 247-251). There is a clear need for additional protein and iron during pregnancy and there may be benefits from augmented amounts of calcium and folate. The desirable amounts of these nutrients increase with the physical activity of the mother.

The mother's physical activity in relation to diet influences growth of the fetus. Ethiopian mothers who engaged in hard physical labor and who had lower that recommended caloric intakes during pregnancy had lower body weights, lower gestational weight gains, and lighter newborns than less active mothers on similar diets (Tafari, Naeye, and Gobezie, 1980). Gambian mothers lost weight during the rainy season, when food was relatively short and agricultural work was at its pre-harvest peak (Hytten and Leitch, 1971, 452-454). American women who worked during the third trimester of pregnancy had newborns who were 150 to 400 grams ( 0.33 to 0.88 pounds) less than newborns of mothers who remained at home (Naeye and Peters, 1982). The growth retardation increased when the work required standing. ${ }^{4}$ Low birth weights attributable to demanding work is a familiar problem in many developing countries, and many antenatal programs now stress the benefits of less work for pregnant women (Ashworth, 1982, 20).

It is well-established that ingestion of toxic substances, such as alcohol and tobacco, during pregnancy will retard fetal growth (Hurley, 1980, 228233). The effects of alcohol are most apparent in alcoholic mothers, whose consumption of alcohol gives rise to a condition called fetal alcohol syndrome. In addition to growth retardation that occurs both prenatally and 
postnatally, these children also suffer birth defects. Consumption of small amounts of alcohol, particularly during the last trimester, also has measurable effects. After adjusting for several other factors that influence birth weight, one study found that for each ounce of absolute alcohol consumed per day during late pregnancy, birth weight declined by 160 grams or 0.35 pounds (Abel, 1982, 427-428). Modern studies have not established a systematic relationship between alcohol consumption and stillbirths (Abe1, 1982, 425-426). Smoking in pregnancy causes an average reduction of 180 grams or 0.40 pounds in fetal weight and a 30 percent increase in perinatal mortality (Tanner, 1978, 46-47). The reduction in size from smoking persists throughout childhood.

There is ample evidence, especially from developing countries, that malnutrition and infection retard growth and development during childhood (Mata et a1., 1971; Frisancho, 1978; Martorel1, 1980; Hurley, 1980; Scrimshaw, 1983). Although all infections adversely affect nutritional status and growth, infections have a profound effect on malnourished children because they reduce food intake and increase the loss of nutrients which are already in short supply. Perhaps the most critical period for young children in this regard is weaning (Knodel and Kinter 1977; Wray, 1978). Breast milk is advantageous for young infants because it is nutritionally ideal, provides some immunity, and is clean. By the time the child is 4 to 6 months of age, breast milk alone is ordinarily inadequate for growth and children are frequently given food supplements. Supplementation, which may begin before age 4 to 6 months postpartum among working women, may result in a less favorable diet and less sanitary conditions. Thus the transition may be responsible for reduced growth and higher rates of $i l 1$ ness and death. 
The data are lacking to appraise all plausible influences that retarded the growth of slave children. Nevertheless enough information is available from height data, plantation records, and other sources to evaluate some hypotheses. The next section emphasizes seasonal patterns of diet, disease, and work among slave mothers and food supplements to infants.

Nutrition and illness (or death) are opposite sides of the same coin. Well-nourished children tend to be healthy and grow while malnourished children have retarded growth and experience higher rates of $i 11$ ness and death. In view of the fact that the height data at ages 1 and 2 probably understate nutritional status before age 3 , information on mortality can be studied for insights into determinants of health and nutrition at these ages. Table 4 shows that deaths up to age 3 were concentrated in the first year and especially the first 8 months of 1 ife. 5 The high mortality rates that prevailed soon after birth suggest that the small stature observed at age 3 and beyond had origins in infancy and possibly the fetal period. The discussion of possible causes therefore begins with conditions during pregnancy.

It should be observed that maternal size influences the size of children (Hytten and Leitch, 1971, 305-310). However, compared to modern height standards slave women were substantially larger than slave children. Slave women attained roughly the 28 th centile of modern height standards and adult slave women were on average about 1.3 inches below the standard. Most of the climb through the centiles occurred while the slaves were teenagers. At age 12, for example, female slaves reached, on average, only centile 1.2 , yet by age 17 they reached 20.6 . This climb toward modern heights was achieved while slaves engaged in heavy physical labor. Other things being equal, this physical activity would have retarded growth. The point is that other things were not 
equal, and specifically the nutritional content of the diet improved when slaves entered the adult labor force. Thus general malnutrition among slave women was a relevant but probably a minor disadvantage to intrauterine and early infant growth. The conditions of stress during childhood combined with a relatively good environment for growth during adolescence distinguish slaves from modern populations. The deprivation in developing countries that produces small children tends to prevail throughout the growing years, and adults are small as a consequence. Referring to Table 3, for example, the Bushnegroes of Surinam attained roughly the 6 th centile at age 3 and adult women in this population attained centile 5.5. Similarly, in India children attained approximately centile 2.0 and adult women reached centile 4.0 .

\section{SEASONAL VARIATION}

Seasonal variation in diet, disease, and work routine by slave mothers is a plausible determinant of fetal and infant growth. Prosperity or deprivation endured seasonably could have had lasting effects on growth and development, particularly if it occurred during a critical period. Seasonal aspects of growth related to diet and work have been documented for agricultural populations in developing countries (Hytten and Leitch, 1971, 452-454).

Unfortunately, height measurements for slaves are unavailable by month of birth, 6 and thus seasonal influences on growth cannot be measured directly. However mortality data from plantation records furnish a substitute source of information. The following discussion examines neonatal and postneonatal infant mortality on plantations that operated between 1786 and 1865 . Neonatal mortality is particularly sensitive to birthweight; the mortality rates rise rapidly as newborn weight declines below 2500 grams or 5.5 pounds (Hytten and Leitch, 1971, 324). 
Although there are 11 planatations for which seasonal data could be studied (details about the units are given in Steckel, 1979b, 90), it is desirable to investigate as a unit farms in which seasonal patterns were approximately the same. The cotton plantations (5 in number) provide the 1 argest number of observations on these grounds. The recording practices on some of these plantations are suspect because the share of neonatal deaths among infant deaths is implausibly low. ${ }^{7}$ Selecting only those plantations that had plausibly high shares, say above 30 percent ( 3 plantations), is one approach to the problem. It is possible, however, that some shares were simply low, and removing these plantations from the sample may bias the results, and for this reason a second group consisting of all five plantations is also studied.

Seasonal phenomena are investigated in connection with a logit regression model (Maddala, 1977, 162-171). The dependent variable is dichotomous and takes on the value of 1 if there was a death within one month of birth and is 0 otherwise. 8 The first equation includes and the second equation excludes stillbirths in the dependent variable. The plausible determinants of neonatal death that are available are mother's age, plantation size as measured by the average number of slaves, year of birth, and month of birth. 9

The influence of mother's age may operate primarily through birth order. Birth weight increases roughly 0.2 pounds from the first to the second child and there is possibly a smaller rise to the third child (Hytten and Leitch, 1971, 301-304). The effects of higher birth orders is ambiguous: some studies show a small trend toward larger size, but with weight falling (for a particular parity) with age of the mother, and others show little or no further change. Increased capacity of the circulatory system to nourish the 
fetus may explain the rise of birth weight with birth order. Mother's age rather than parity is used in the regression because these variables are highly correlated and because mother's age is known reliably for more observations.

Plantation size may have influenced neonatal mortality through the work routine, the disease environment, and supplementation practices. The labor demands on slaves were probably greater on large units (Fogel and Engerman, 1974, 203-206). The fact that owners of small units ordinarily worked along with the slaves may have contributed to an easier pace. Overseers and driver achieved an intensive work routine through the gang system that characterized 1 arge farms. Thus claims on the diet may have been greater on large plantations, but interviews with ex-slaves suggests that diets were about the same on small and large plantations (Crawford 1980, 123). The numbers on large plantations may have increased the chances that someone nearby harbored a communicable disease. Slaves on large plantations may have had greater access to hospitals and medical care, but many early nineteenth century medical practices no doubt increased the probability of death. If the disease environment deteriorated with plantation size, then the health of pregnant women and the nourishment of the fetus may have declined with this variable. If slave women were relatively more productive in field work on large units (Fogel and Engerman, 1974, 192-194), this would have encouraged supplementation of the infants' diet at an earlier age. Thus the disease environment on large plantations could have compounded the problems arising from early supplementation.

The probable effect of time on neonatal mortality rates is unclear because many, possibly opposing, changes that are not in the regression could 
have occurred. The disease environment, for example, could have become more or less severe. Similarly, changes in breastfeeding practices, the intensity of work, or diets may have occurred over time. One can speculate about possible influences that were correlated with time, but it would be difficult to identify the specific sources of change given that little is known about the details of operation on these particular plantations.

Table 5 shows the regression results. The first equation includes stillbirths in the dependent variable and pertains to cotton plantations for which the recorded share of infant deaths that occurred within 28 days of birth was at least 30 percent. As a way to adjust for probable underreporting, the regression for all cotton plantations also includes the share of infant deaths that occurred within 28 days as an independent variable. On these grounds the coefficient has the expected sign, but the t-value is only 1.35 and other coefficients change little if the variable is omitted from the equation. The statistic $-2 \log \lambda$ has a chi-square distribution with as many degrees of freedom as there are regressors (except the constant), and the values reported at the bottom of the table show that the regressions are significant at approximately 0.17 and 0.07 , respectively.

As expected, deaths in early infancy were greatest among young mothers. If other independent variables are evaluated at their sample means, the probability of early infant death in the first equation was about 14.6 percent for women under age 20 and about 4.1 percent for women aged 20-24. Although the individual coefficients are not statistically significant, the pattern of coefficients in both equations at higher ages suggests that probabilities of early death approached those for births to young women as age increased. Plantation size had no systematic influence on early death in either equation. In assessing this result it is important to remember that the 
plantations in the sample were large by standards of the American South. The smallest unit in the sample, for example, had about 65 slaves. Within the range of observation size may have had no effect, but it is perhaps worth noting that regressions on height from Civil War military records show that the heights of blacks declined as the median size of holding in the county of residence increased (Margo and Stecke1, 1982).

The data for the first equation are not wel1-suited to examine the influence of time because there are no observations for the late 1820 s or the early 1830s. The data for the second equation are only slightly better in this regard. While keeping this feature of the data in mind, statistical tests were conducted on the time coefficients, and one cannot reject the null hypothesis (at a significance level in excess of 0.25 ) that time had no influence on early death. This finding holds if time period dummies replace the polynomial in time.

As a group the month of birth coefficients are statistically significant at 0.05 in each equation. Limited observations in the first equation required that births be combined in May and June and in July and August. The pattern of the coefficients establishes a peak in late winter and early spring centered in March and a second, smaller concentration of early deaths for births from September through November. Table 6 converts these coefficients into probabilities by evaluating other independent variables at their sample means. The pattern of probabilities is similar in both equations, but the seasonal extremes are dampened in the second equation; this contrast is consistent with consistent with a higher rate of underenumeration in the second compared to the first data source. The seasonal differences are enormous in both equations. In the first equation the average probability in the highest 6 months 
which is a ratio of 5.1 to 1 . In the second equation the figures are 10.0 percent, 3.7 percent, and a ratio of 2.7 to 1 .

Underlying factors that may have been responsible for this seasonal pattern include diet, disease, work, and supplementation practices. nur knowledge of seasonal variations in these determinants is an important limitation and so pieces of the puzzle are missing, but the available knowledge combined with mortality data and information from modern studies of fetal and early childhood growth suggest a rough sketch of what may have been the actual process.

The discussion of seasonal influences begins with the harvest because it was the longest period of intense labor. The harvest for the cotton plantations in the mortality sample ordinarily extended from late August through mid December (Covert, 1912, 96). The harvesting of other crops such as corn may have coincided with the end of the cotton harvest and extended into the next year. It is clear, however, that harvesting cotton was the most valuable of these activities. Table 7 shows women's output in this activity in the weeks before and after childbirth. 10 output fell gradually as childbirth approached, then plumeted from a week before to 3 weeks after birth, and rose rapidly within 4 weeks after birth. The rapid rise in output suggests that interruptions for breastfeeding may have been sufficiently few (or nonexistent) that they were a factor in neonatal mortality.

Modern studies suggest that seasonal patterns of diet and work effort may have influenced perinatal (stillbirth and early neonatal) mortality rates. If conditions are satisfactory during the early stages of pregnancy, the mother accumulates reserves of fat that protect the fetus against short periods of deprivation (Hytten and Leitch, 1971, 383-387). The greatest need for these 
reserves in promoting weight gain occurs in the last trimester of pregnancy, particularly weeks 28-36 (full term is 40 weeks), when the weight gain of the fetus is ordinarily greatest (Tanner, 1978, 42). Recall from section two of the paper that the outcome of pregnancy is particularly sensitive to conditions in the first and the last trimesters.

Children born during the harvest were conceived early in the year, and the course of diet, work, and disease in ensuing months could easily have affected their fortunes. Nominally the diet was probably best from mid-summer through early winter: by July fresh vegetables were available and the slaughter of livestock began as early as late autumn. A poor diet during the spring may have inhibited the accumulation of fat reserves, and though the hoeing season of mid May through June lasted only a few weeks, its physical demands were considerable. Diseases among adults of childbearing age were greatest during the summer (Steckel, 1979b, 108), and malnutrition related to 111 ness could have contributed to the process by retarding the accumulation or depleting fat reserves. If summer diseases were relatively unimportant, July and August may have been favorable months, particularly for children born in September or October, because the diet was reasonably good and work loads were relatively light. If the requirements of physical activity were sufficiently great, the depletion of fat reserves could have begun in late August. If and when they may have been depleted is not clear, but mortality data discussed below shed right on this question.

The consequences of first trimester deprivation, last trimester deprivation, and early supplementation differ. If deprivation during the first trimester was primarily responsible for pregnancy losses then stillbirths would have been frequent. If deprivation during the last trimester was primarily responsible then stillbirths would have been relatively frequent, birth 
weights would have been $1 \mathrm{ow}$, and deaths would have been concentrated almost immediately after birth. If supplementation soon after birth was primarily responsible then stillbirths would have been relatively infrequent, birth weights would have been relatively high, and survival rates would have been relatively high immediately after birth but low for the remainder of the first month. Table 8 shows that the timing of deaths occurring within the first six months varied considerably by month of birth. Row 3 of the table shows that losses for births early in the harvest--from August through October--were concentrated after the first day and particularly after the first week. In contrast, losses late in the harvest--November-December--were concentrated among stillbirths and deaths within the first day and were relatively low in the remainder of the first month. Based on a chi-square test of homogeneity the August-October and the November-December distributions are significantly different at 0.15 .11 The picking records show that it took nearly one month after birth to reach high productivity, and the low number of deaths from the second day through the second month suggests that women who gave birth late in the harvest may have delayed supplementation. The contrast between rows 3 and 4 of the table suggests that early supplementation was primarily responsible for neonatal deaths early in the harvest, but low birth weights were primarily responsible late in the harvest. Depletion of fat reserves during the harvest may have reduced the weight of births that occurred late in the harvest, and deprivation during the planting and hoeing seasons may have caused the large share of stillbirths that occurred late in the harvest. The effects of first trimester deprivation on the outcome of pregnancy is persuasive in view of efforts by owners and overseers to prevent shirking. Pregnant women may not have received lighter work loads until there was visible change in outward appearance, probably during the fifth month (Campbe11, 1984, 802). 
The probability of death within one month of birth was also high from February through April. These children were conceived from late spring through early summer and thus the mother's diet was nominally good throughout most of the fetal period. The major strain on these pregnancies arising from physical exertion must have occurred during the harvest. Yet the diet was probably best from late fall through early winter when consumption of fresh meat was greatest.

Work loads diminished in December and they were probably lower in January than at any other time of the year. The plowing season began in February, but plowing was heavy work usually reserved for men. The planting seascn of March and early April was the next major period of labor for women. The planting season was relatively brief, however, and it occurred too late to have had much influence on birth weights in April.

The distributions in rows 1 and 2 of Table 12 are significantly different at 0.05 . The above-average loss rate from stillbirths in February-April is probably related to strains of the harvest during the first trimester, but the high mortality rate within one day of birth in this period suggests that low birth weight or other complications of pregnancy also characterized these children. If food intake and work in the last trimester were not responsible, then alcohol may have been. Although slaveowners generally discouraged liquor consumption by slaves, exceptions were often made at Christmas, New Year's, and at other gatherings to celebrate the harvest (01mstead, 1861, 76-77; Stampp, 1956, 169-170, 370-371; Genevose, 1974, 556-584). S1 aves may have had the means to purchase liquor from cash bonuses earned during the harvest or from the sale of hogs, chickens, eggs, and garden produce. Liquor cost about 25 cents per gallon (Cole, 1938) and slaves could purchase it from poor whites, peddlers, and shopkeepers. Thus liquor consumption may have remained 
high, at least for some slaves, from the end of the harvest in mid December through the winter.

Although the actual amount of alcohol consumed and its effects on slaves are unknown, the available information suggests that alcohol consumption during the last trimester may have been an important factor in the high rate of perinatal deaths in February-Apri1. It is clear, however, that other factors such as stillbirths resulting from first-trimester exertion relative to diet during the harvest may have been involved. If alcohol consumption declined substantially by February, then physical exertion of the planting season combined with a nutritionally diminishing diet may have contributed. The relatively high share of deaths from days 7-29 also suggests that early supplementation, perhaps associated with labor demands for planting, may have been relevant.

\section{OTHER FACTORS}

The previous section examined seasonal aspects of diet, disease, and work that operated during critical periods of pregnancy and through food supplements to young infants. This section emphasizes smoking and alcohol consumption during pregnancy, determinants of post-neonatal infant mortality, and the child's diet during and after weaning. Although the effects of toxic substances such as alcohol and tobacco on pregnancy and its outcome are wel1known today, slaveowners and slaves had no systematic information on their consequences for health. Slaveowners probably thought that the major cost of alcohol was disruption of the work force, a cost that was particularly high during seasonal peaks in the demand for labor. Smoking and chewing tobacco did not have these costs. Tobacco was widely grown throughout the South (U.S. Census 0ffice, 1864, 184-185) and thus slaves may have been able to raise 
their own. Slaves may have spent a considerable portion of their money or exchangeable goods for tobacco (Genevose, 1974, 644). While the information necessary to measure the effects of alcohol and tobacco consumption during pregnancy is unavailable, these products were probably not the primary cause of small stature among slave children because they permanently stunt growth. The fact that slave adults exceeded the 25 th centile of modern height standards implies that other factors were important.

While birthweight is a major determinant of early mortality, if a child survives the first month of 1 ife the chances of survival for the remainder of the first year depend heavily on diet and disease. The approach taken to the analysis of postneonatal infant mortality is similar to that employed for neonatal mortality. The plausible explanatory variables that are available for the logit regression model are sex, plantation size (number of slaves), main crop, year of birth, and month of birth. To the extent that diet and disease as opposed to birth weight contributed to neonatal mortality, the motivation of these variables is similar to that discussed in the section on neonatal mortality. Differences in the motivation are highlighted in the discussion below of the results in Table 9 .

The net effect that gender might have had on postneonatal mortality is not clear. Some societies emphasize male children and devote relatively more resources to their survival, but whether this was encouraged or permitted and whether it was effective if practiced among slaves is unknown. As early as mid-way through the fetal period girls are more developed than boys and at birth the difference corresponds to 4 to 6 weeks of maturation (Tanner, 1978, 58). The advantage of earlier maturation may have reduced mortality rates among females after the first month of life. Since the relative advantage of 
females tends to diminish as the mortality level rises (United Nations, 1973, 115-118), it is perhaps not surprising that the coefficient of the gender variable is small and positive but statistically significant.

Many studies have noted that perinatal mortality rates rise with advancing age of the mother, particularly after age 30 (United Nations, 1973, 127). One might suppose that some of the disadvantages which mother's age conveyed to losses before the first month would carry over to later periods of infancy, and on these grounds the sharp decline in postneonatal mortality rates with mother's age may seem surprising. If other independent variables are evaluated at their sample means, the probability of postneonatal death was 24.0 percent for mothers under age 20 but only 10.1 percent for mothers aged 30 or more. If. the first month was so harsh that it eliminated marginal children who would ordinarily have perished in the postneonatal period, then postneonatal mortality rates should have been high for mothers' ages at which neonatal mortality rates were 10 . Yet rates were highest in both periods for young mothers. The value of womens' time by age could have been a contributing factor. Annual net earnings of slave women peaked in the late 20s (Fogel and Engerman, 1974, 76), and older women may have devoted relatively more time to breastfeeding or other aspects of child care. However, the fact that annual net earnings were uniformly higher in the 30 s than they were before age 20 suggests that other factors were involved. Postneonatal mortality may have declined with age simply because experience was important in improving child care.

Postneonatal mortality rates systematically increased with plantation size as measured by the number of slaves. For example, the expected probability of death was about 8.4 percent at size 75 but 13.8 percent at size 200 . Although no systematic association was found between size and neonatal mortality, the 
neonatal mortality, the motivation developed in that section is plausible here. More specifically, mortality rates may have risen because the disease environment deteriorated or possibly because more extensive specialization and division of labor made field labor relatively more productive and child care relatively more expensive.

The finding that postneonatal mortality rates were lower on sugar plantations suggests that the poor reputations of the crop and the areas in which it was grown may be undeserved. The expected mortality rate was 14.9 percent on cotton plantations but only 6.6 percent if sugar was the main crop. The mortality rates in rice and mixed farming were not systematically different from that on cotton farms. Furthermore, if the entire sample and the regression model of Table 9 are applied to neonatal mortality, the coefficients of the crop variables as a group are statistically significant at greater than 0.25. Before considerable energy is devoted to reconciling these results with preconceptions, it should be recognized that there is only one sugar plantation in the sample. This qualification aside, the fact that sugar plantations tended to be very large may explain the high mortality rates often associated with the crop and the region. It is also possible that the work routine, which often required heavy labor for ditching and plowing (Gray, 1933, 749-751), may have freed womens' time for postneonatal care. Breastfeeding may have been abbreviated during the harvest, but labor demands for women could have been relatively even and low during the rest of the year such that breastfeeding was encouraged.

Although the dates of seasonal work patterns differed by main crop, the common pattern was that crops were planted in the spring and harvested in the fal1. The common seasonal fluctuations might have generated systematic seasonal patterns of postneonatal mortality that operated through the age at 
which infants received food supplements and possibly through seasonal patterns in the quality of the diet or the severity of the disease environment. No systematic pattern appears in the month of birth coefficients. These coefficients are jointly significant at greater than 0.25 , and this result holds if the test is performed on data for cotton plantations only. One possible interpretation of these findings is that supplementation occurred uniformly early--so early that differences across periods of time as large as a month are not readily discernible. Another is that other important factors, such as the conditions of the mother and the child and the value of the mother's time in other activities dominated seasonal influences which may have been present. A third interpretation is that seasonal patterns of supplementation, diet, and disease existed but their consequences for mortality were so diffused over weeks or months that they obscured the underlying seasonal phenomena.

Food supplements to infants may have begun within a few weeks after birth among children born during periods of intense labor requirements. Previous discussion has emphasized the consequences of poor sanitation surrounding food supplements. These problems aside, the longer term prospects for growth depended upon the nutritional content of the diet during and after weaning. The diet was insufficient to promote catch-up growth probably because it lacked protein and certain vitamins and minerals such as calcium and iron. Planters were apparently convinced that the child's intake should emphasize cornbread, hominy, and fat (Kiple and King 1981, 97). Medical writers of the era did little or nothing to challenge this view. At the close of the eighteenth century it was common to breastfeed young infants but pap was soon added to the child's diet (Wickes, 1953, 336-338). By the mid-nineteenth century some writers argued for the addition of diluted cows milk, but it is clear that the recommended weaning diet emphasized starchy foods such as panada and gruel. 


\section{CONCLUDING REMARKS}

It is well established that stature or height is an excellent index of health. Estimates of height imply that the average slave child was in poor health. Slave children on average fell below the first centile of modern height standards until age 5 and were approximately the same size as children from the poorest populations in developing countries. Sources of deprivation can be traced to conditions during pregnancy and during the first year of 1ife. Mortality data discussed in the paper are consistent with the argument that fluctuations in diet relative to the work routine and seasonal patterns of disease and consumption of alcohol created stress during initial periods of fetal development. Seasonal peaks in the demand for labor may have established patterns of food supplementation to infants that also contributed to seasonal aspects of health. Post-neonatal death rates, and by implication diseases that retarded growth, systematically increased with plantation size. Tobacco was widely used throughout the South, and many slave women could have smoked during pregnancy.

The collection of plausible determinants of health among slave children is consistent with diversity in this population. Fortune or misfortune began with the month of conception; those lucky enough to pass through critical periods of intrauterine development with little or no stress had a relatively good start in life. On average misfortune befelled those children whose mothers were young, smoked, consumed alcohol, and who resided on large plantations. Children who missed most of the pitfalls during the growing years on average reached or approached modern heights.

Additional insights into the diversity of the slave population may be available through regional and temporal studies. Plantation records having 
mortality information are limited in this respect, but sufficient height data are available for study by the major areas of supply to the coastal trade in slaves. The absence of famines in the United States suggests that nutritional conditions may have been approximately constant over time, but net nutrition available for physical growth after claims made by disease and physical exertion, could have fluctuated as a result of epidemics or changes in slave work routines. Since the heights of children are sensitive to immediate conditions, the slave manifests are potentially an important source for understanding the temporal dimensions of health in the antebellum South. 
FOOTNOTES

1. The slave manifest data originated with efforts by congress to prevent slave smuggling after the close of the Atlantic slave trade in 1807 . Heights were used to identify slaves involved in the coastwise trade, which was legal after 1807. Steckel (1979a) describes aspects of these data. The data base for this paper consists of the data used in the 1979 paper plus all manifests housed in the National Archives under the port of Savannah.

Owners maintained lists of slave births and deaths as a means of monitoring demographic performance. The plantation records employed in this paper are described in Steckel (1979b) and consist of 11 units that grew cotton, rice, or sugar in South Carolina, Georgia, Alabama, and Louisiana between 1786 and 1865. See Steckel (1982, 1985c) for additional details about slave demographic records.

2. Comparisons across populations should be made cautiously because of the possible role of genetic differences. In this regard it is important to distinguish genetic influences on individuals from genetic influences on entire populations. It is clear that genes are important determinants of the heights of individuals, but studies involving genetically similar and dissimilar populations under various environmental conditions suggest that differences in average height across most populations are largely attributable to environmental factors (Habicht et al., 1974: Malcolm, 1974). Comparisons of Far-Eastern adults with other populations are an exception that may have a substantial genetic basis; well-off Japanese, for example, reach, on average, the fifteenth centile of well-off Britains (Tanner et 
al., 1982). With regard to possible genetic factors in comparisons involving U.S. STaves, Europeans, and II.S. whites, it is useful to note that we 11-nourished populations of Europeans, Americans of European descent, and Americans of African descent have approximately the same average heights today (Eveleth and Tanner, 1976, appendix).

3. The reliability of the data can be investigated on two grounds: possible biases in the manifests vis-a-vis the entire population of American slaves, and the accuracy of recording phenomena purported to have been measured. Steckel $(1979 a, 1985 a)$ discusses these issues. While recognizing that biases and errors may contaminate the data, the distortions were probably sufficiently small that it is reasonable to accept the estimates at face value at ages 3 and above.

4. The effects of the mother's work on fetal growth may be the consequence of maladaptation by humans to an upright posture. See Briend (1979; 1980) and Hytten (1981).

5. Plantation owners may have failed to record some deaths, especially those occurring soon after birth. Steckel (1979b) discusses this issue, and Steckel (1985b) estimates that neonatal mortality (deaths up to 28 days after birth) probably exceeded 15 percent.

6. Occasionally the manifests listed age in months for children under 1 year of age.

7. Based on births and deaths for which the month, day, and year of birth and death are known. 
8. What is measured is called neonatal mortality although neonatal mortality actually includes only deaths from 0 to 28 days. The dependent variable overestimates neonatal mortality because it includes deaths that occurred up to 1 calendar month after the calendar month of birth.

9. One could argue that sex of the child should be included in the regression on the grounds that neonatal mortality rates tend to be higher among male children. However, the sex was not reported for an imortant share of deaths that occurred soon after birth. If sex is included in a regression involving observations in which the sex is known, the coefficient has a t-value of .26 in the first equation and .40 in the second equation. If sex is included, the seasonal pattern of coefficients changes such that probabilities of death are relatively lower during September and nctober.

10. The data are based on weekly picking records of fifteen female slaves on the Leak plantation who gave birth a total of 28 times between 1841 and 1860. In a study of the Kollock plantations, Campbe11 (1984, 807) finds that women returned to the fields, on average, 25.2 days after birth $(N=60)$.

11. Ordinarily a significance level of 0.15 would not be cited as evidence of a difference in behavior. However, given the potential for underenumeration of early deaths (discussed and measured in Steckel (1985b)), the actual seasonal extremes must have been considerably greater than those evident in these data. 
Table 1

Mean, Standard Deviation, and Velocity of Slave Heights, Ages 1-6

\begin{tabular}{ccccccccc}
\hline & \multicolumn{3}{c}{ MALES } & \multicolumn{5}{c}{ FEMALES } \\
\cline { 2 - 5 } & Mean & s.d. & $N$ & Velocity & Mean & s.d. & N & Velocity \\
\hline 1 & $23.88^{\mathrm{a}}$ & 4.65 & 96 & & $23.64^{\mathrm{a}}$ & 5.58 & 91 \\
2 & $29.17^{\mathrm{a}}$ & 5.35 & 136 & 5.29 & $29.50^{\mathrm{a}}$ & 5.42 & 148 & 5.86 \\
3 & 33.35 & 5.20 & 187 & 4.19 & 32.65 & 4.93 & 168 & 3.15 \\
4 & 35.91 & 5.53 & 195 & 2.56 & 35.92 & 5.46 & 206 & 3.27 \\
5 & 38.25 & 5.29 & 169 & 2.34 & 38.98 & 5.19 & 200 & 3.05 \\
6 & 40.63 & 5.31 & 218 & 2.38 & 40.01 & 5.76 & 262 & 1.04 \\
\hline
\end{tabular}

Source: Slave manifests.

a. Probably biased downward. See text. 
Table 2

Slaves Compared to Modern Height Standardsa

\begin{tabular}{|c|c|c|c|c|c|c|c|c|c|c|}
\hline \multirow[b]{2}{*}{ Age } & \multicolumn{5}{|c|}{ MALES } & \multicolumn{5}{|c|}{ FEMALES } \\
\hline & Modern & $\begin{array}{l}\text { Modern- } \\
\text { Slave }\end{array}$ & $\begin{array}{c}\text { Modern } \\
\text { s.d. }\end{array}$ & $\begin{array}{r}\text { s.d. } \\
\text { below } \\
\text { modern }\end{array}$ & $\begin{array}{l}\text { Centile } \\
\text { of } \\
\text { Modern }\end{array}$ & Modern & $\begin{array}{l}\text { Yodern- } \\
\text { Slave }\end{array}$ & $\begin{array}{c}\text { Modern } \\
\text { s.d. }\end{array}$ & $\begin{array}{l}\text { s.d. } \\
\text { below } \\
\text { modern }\end{array}$ & $\begin{array}{l}\text { Centile } \\
\text { of } \\
\text { Modern }\end{array}$ \\
\hline 1 & 32.32 & 8.44 & 1.69 & 4.99 & $0.00003^{b}$ & 31.69 & 8.05 & 1.76 & 4.59 & $0.0002^{b}$ \\
\hline 2 & 35.51 & 6.34 & 1.69 & 3.75 & $0.01^{b}$ & 35.00 & 5.50 & 1.70 & 3.24 & $0.06^{b}$ \\
\hline 3 & 38.58 & 5.23 & 1.81 & 2.89 & 0.2 & 38.11 & 5.46 & 1.81 & 3.02 & 0.1 \\
\hline 4 & 41.34 & 5.43 & 1.94 & 2.80 & 0.3 & 40.87 & 4.95 & 1.94 & 2.55 & 0.5 \\
\hline 5 & 43.90 & 5.65 & 2.07 & 2.73 & 0.3 & 43.43 & 4.45 & 2.07 & 2.15 & 1.6 \\
\hline 6 & 46.30 & 5.67 & 2.20 & 2.58 & 0.5 & 45.83 & 5.82 & 2.20 & 2.65 & 0.4 \\
\hline
\end{tabular}

Source: Table 1 and calculated from Tanner, Whitehouse, and Takaishi (1966).

a. The mean and standard deviation of height for modern standards was determined at age $n+1 / 2$. For example, the height of 32.32 used for males at age 1 is the modern standard at exact age 1.5 . This practice is consistent with the aggregation of exact ages 1.0 to 1.99 for the group that was age 1 at last birthday. It is important to note that the standard deviation reported for modern standards at, say exact age 1.5, is an "instantaneous" measure that must be augmented to compensate for the greater variance of heights that results from age aggregation within the age interval 1.0 to 1.99 (see Healy, 1962). This adjustment is particularly important for ages in which growth is rapid.

b. Average heights at these ages are probably biased downward and the results should be viewed skeptically. See the text for additional discussion. 
Table 3

Centile of Modern Height Standards Achieved at Age 3 by the Average Child in Various Populations in Developing Countries and by U.S. Slaves

\begin{tabular}{cccc} 
& & \multicolumn{2}{c}{ Centile } \\
Country & $\begin{array}{c}\text { People or } \\
\text { Place }\end{array}$ & Males & Females \\
\cline { 3 - 4 } Nigeria & Lagos (s7um) & 12.1 & 6.4 \\
Surinam & Bushnegroes & 6.6 & 5.8 \\
Gambia & Keneba & 3.8 & 6.7 \\
India & National & 2.5 & 1.8 \\
Rolivia & Mixed & 1.0 & 0.7 \\
Bangladesh & Urban & 0.3 & 0.4 \\
U.S. & Slaves & 0.2 & 0.1 \\
\hline
\end{tabular}

Source: Table 2 and calculated from Eveleth and Tanner (1976) Appendix Tables $40,41,57,58,73$, and 74 . 
Table 4

Slave Mortality Rates in Early Childhood

\begin{tabular}{|c|c|c|}
\hline Month After Birth & $\begin{array}{l}\text { Number of Deaths per } \\
1000 \text { Survivors to the } \\
\text { Beginning of the Interval }\end{array}$ & $\begin{array}{l}\text { Number of Survivors } \\
\text { to the Beginning } \\
\text { of the Interval }\end{array}$ \\
\hline $1-2$ & 54 & 2,002 \\
\hline $3-4$ & 45 & 1,893 \\
\hline $5-6$ & 28 & 1,808 \\
\hline $7-8$ & 39 & 1,757 \\
\hline $9-10$ & 26 & 1,689 \\
\hline $11-12$ & 22 & 1,645 \\
\hline $13-14$ & 22 & 1,609 \\
\hline $15-16$ & 26 & 1,573 \\
\hline $17-18$ & 16 & 1,532 \\
\hline $19-20$ & 15 & 1,507 \\
\hline $21-22$ & 16 & 1,485 \\
\hline $23-24$ & 12 & 1,461 \\
\hline $25-26$ & 10 & 1,443 \\
\hline $27-28$ & 9 & 1,428 \\
\hline $29-30$ & 10 & 1,415 \\
\hline $31-32$ & 7 & 1,401 \\
\hline $33-34$ & 6 & 1,391 \\
\hline $35-36$ & 7 & 1,382 \\
\hline
\end{tabular}

Source: Plantation records.

Note: As used here month refers to calendar months after birth. For example, July is the first month after birth for a child born in June. This approach is taken because owners sometimes failed to record day of birth or day of death. 
Table 5

Regression of Death within One Calendar Month on Mother's Age, Plantation Size, the Recorded Proportion Who Died within 28 Days, Time Period and Month of Birth

\begin{tabular}{|c|c|c|c|c|}
\hline \multirow[b]{2}{*}{ Variable } & \multicolumn{2}{|c|}{ Rate $>.30^{a}$} & \multicolumn{2}{|c|}{ Al1 Plantations } \\
\hline & Coeff. & $t$-value & Coeff. & t-value \\
\hline Mother Aged 20-24 & -0.8980 & -1.53 & -0.9656 & -1.82 \\
\hline Mother Aged 25-29 & -0.9501 & -1.51 & -1.051 & -1.88 \\
\hline Mother Aged 30-34 & -0.5516 & -0.87 & -0.5610 & -1.03 \\
\hline Mother Aged 35+ & 0.1098 & 0.17 & -0.6808 & -1.16 \\
\hline Plantation Size & 0.005011 & 0.53 & -0.001308 & -0.42 \\
\hline Prop. Who Died within 28 Days & & & 2.234 & 1.35 \\
\hline Year Birth 1 & -19.857 & -1.14 & -19.373 & -1.27 \\
\hline Year Birth 2 & 8.3011 & 1.40 & 8.2593 & 1.61 \\
\hline Year Birth 3 & -1.6354 & -1.39 & -1.5938 & -1.63 \\
\hline Year Birth 4 & 0.15662 & 1.27 & 0.14425 & 1.49 \\
\hline Year Birth 5 & -0.0058487 & -1.17 & -0.0050026 & -1.34 \\
\hline February & 0.7769 & 0.52 & 1.287 & 1.31 \\
\hline March & 2.691 & 2.27 & 1.345 & 1.50 \\
\hline Apri 1 & 1.431 & 1.23 & 1.023 & 1.20 \\
\hline May or June & 0.5897 & 0.51 & 0.2840 & 0.34 \\
\hline JuTy or August & -0.1654 & -0.13 & -0.4031 & -0.45 \\
\hline September & 1.886 & 1.57 & 0.8807 & 0.99 \\
\hline October & 1.350 & 1.10 & 0.4180 & 0.43 \\
\hline
\end{tabular}


Table 5 (cont'd)

\begin{tabular}{lcccr}
\hline & \multicolumn{2}{c}{ Rate $>.30^{\mathrm{a}}$} & \multicolumn{2}{c}{ All Plantations } \\
\cline { 2 - 5 } Variable & Coeff. & t-value & Coeff. & t-value \\
\hline November & 1.635 & 1.43 & 0.4935 & 0.54 \\
December & 0.9397 & 0.79 & -0.6212 & -0.59 \\
Constant & 12.352 & 0.58 & 12.606 & 0.63 \\
& & & & \\
& $N$ & & & \\
& $N=284,-2 \log \lambda=24.82$ & $N=568,-2 \log \lambda=29.72$ \\
\hline
\end{tabular}

Source: Cotton plantation birth and death lists.

Definition of Variables: Dependent variable $=1$ if the child died within one calendar month of birth, 0 otherwise; Year Birth $i=(($ year of birth-1770)/ $10)^{i}$; the definitions of other variables are clear from the table. The omitted variables are mothers Age Less Then 20, and January.

a. Includes stillbirths. 
Table 6

The Probability of Death within One Calendar Month of Birth by Month of Birth and Data Sourcea

\begin{tabular}{lcc}
\hline Month of Birth & Rate $>.30^{\mathrm{b}}$ & A11 \\
\hline January & .038 & .039 \\
February & .079 & .143 \\
March & .366 & .136 \\
April & .141 & .105 \\
May or June & .066 & .053 \\
July or August & .032 & .027 \\
September & .205 & .093 \\
October & .131 & .059 \\
November & .167 & .065 \\
December & .091 & .022 \\
\hline
\end{tabular}

Source: Calculated from Table 5.

a. Probability per month of 30.4 days.

b. Includes stillbirths. 
Table 7

Daily Cotton Picking Rates Before and After Birth

\begin{tabular}{lcc}
\hline Time Period & Rate (Tbs.) & Percent \\
\hline $9-12$ Weeks Before & 73.2 & 83.4 \\
$5-8$ Weeks Before & 69.2 & 78.8 \\
$1-4$ Weeks Before & 67.0 & 76.3 \\
Week of Birth and Week After & 31.3 & 35.6 \\
$2-3$ Weeks After & 8.6 & 9.8 \\
$4-7$ Weeks After & 58.9 & 67.1 \\
8-11 Weeks After & 80.6 & 91.8 \\
Other Weeks & 87.8 & 100.0 \\
\end{tabular}

Source: Calculated from Metzer (1974, 27-28).

a. Assumes the woman was 25 years old. 
Table 8

Mortality Rates per Thousand by Month of Birth and Day After Birth

Days from Birth to Death

\begin{tabular}{|c|c|c|c|c|c|c|c|c|}
\hline Month of Birth & $\begin{array}{l}\text { Sti11- } \\
\text { births }\end{array}$ & $0-1$ & $2-6$ & $7-29$ & $30-59$ & $60-89$ & $90-180$ & $\begin{array}{c}\text { mber of } \\
\text { Still- } \\
\text { births } \\
\text { plus } \\
\text { Births }\end{array}$ \\
\hline Jan., May, June, Juły & 0 & 8 & 21 & 24 & 35 & 28 & 58 & 387 \\
\hline Feb., March, April & 18 & 36 & 19 & 43 & 40 & 10 & 53 & 224 \\
\hline Aug., Sept., Oct. & 3 & 10 & 23 & 36 & 10 & 14 & 39 & 314 \\
\hline Nov., Dec. & 31 & 21 & 16 & 11 & 11 & 23 & 46 & 194 \\
\hline A1 1 Months & 10 & 17 & 21 & 30 & 26 & 20 & 50 & 1119 \\
\hline
\end{tabular}

Source: Five cotton plantations, observations in which month, day, and year of birth and death are reported. Three of these plantations systematically reported stillbirths and one occasionally reported stillbirths. 
Table 9

Regression of Mortality from 2 to 11 Months on Sex, Mother's Age, Plantation Size, Main Crop, Year of Birth, and Month of Birth

\begin{tabular}{|c|c|c|}
\hline Variable & Coefficient & t-value \\
\hline Fema le & 0.02266 & 0.11 \\
\hline Mother Aged 20-24 & -0.6245 & -2.00 \\
\hline Mother Aged 25-29 & -0.7980 & -2.33 \\
\hline Mother Aged 30-34 & -1.030 & -2.71 \\
\hline Mother Aged 35+ & -1.046 & -2.70 \\
\hline Plantation Size & 0.00450 & 3.33 \\
\hline Mixed Farming & 0.1422 & 0.34 \\
\hline Rice & 0.00206 & 0.01 \\
\hline Sugar & -0.9019 & -2.22 \\
\hline Year Birth 1 & -3.7260 & -0.37 \\
\hline Year Birth 2 & -1.4390 & -0.44 \\
\hline Year Birth 3 & 0.79051 & 1.34 \\
\hline Year Birth 4 & -0.10884 & -1.91 \\
\hline Year Birth 5 & 0.0047377 & 2.20 \\
\hline February & 0.2012 & 0.34 \\
\hline March & 0.8418 & 1.62 \\
\hline Apri 1 & 0.0363 & 0.07 \\
\hline May & 0.1761 & 0.35 \\
\hline June & -0.4530 & -0.84 \\
\hline July & 0.0893 & 0.17 \\
\hline August & -0.0915 & -0.18 \\
\hline September & 0.0585 & 0.12 \\
\hline
\end{tabular}


Table 9 (cont'd)

\begin{tabular}{lcc}
\hline \multicolumn{1}{c}{ Variable } & Coefficient & t-value \\
\hline October & 0.2267 & 0.42 \\
November & -0.3202 & -0.55 \\
December & 0.2891 & 0.59 \\
Constant & 5.928 & 0.44 \\
\hline$N=743,-2 \log \lambda=46.062$ & \\
\hline
\end{tabular}

Source: Plantation Records.

Note: The dependent variable equals 1 if a child

who survived to the second calendar month died

before or within the eleventh calendar month and

is 0 otherwise. Other variables, if not self-

explanatory, are defined in the notes to Table 5 .

The omitted variables are Mother Aged Less Than

20, Cotton, and January. 


\section{REFERENCES}

Abel, E.L. 1982. Consumption of Alcohol During Pregnancy: A Review of Effects on Growth and Development of Offspring. Human Biology 54: 421 453.

Ashworth, A. 1982. International Differences in Infant Mortality and the Impact of Malnutrition: A Review. Human Nutrition: Clinical Nutrition $36 c: 7-23$.

Blanco, R.A., R.M. Acheson, C. Canosa, and J.B. Solomon. 1974. Height, Weight, and Lines of Arrested Growth in Young Guatemalan Children. American Journal of Physical Anthropology 40: 39-47.

Briend, A. 1979. Fetal Malnutrition--The Price of Upright Posture? Rritish Medical Journal 2: 317-319. - 1980. Maternal Physical Activity, Birth Weight and Perinatal Mortality. Medical Hypotheses 6: 1157-1170.

Campbe11, J. 1984. Work, Pregnancy, and Infant Mortality Among Southern Slaves. Journal of Interdisciplinary History 14: 793-812.

Cole, A.H. 1938. Wholesale Commodity Prices in the United States, 1700-1861. Cambridge: Harvard.

Crawford, S.C. 1980. Quantified Memory: A Study of the WPA and Fisk University Slave Narrative Collections. Ph.D. dissertation, University of Chicago.

Covert, J.R. 1912. Seedtime and Harvest: Cereals, Flax, Cotton, and Tobacco. USDA Bureau of Statistics Bulletin 85. Washington: Government Printing office.

Eltis, D. 1982. Nutritional Trends in Africa and the Americas. Journal of Interdisciplinary History 12: 453-475. 
Eveleth, P.B. and J.M. Tanner. 1976. Worldwide Variation in Human Growth. Cambridge: Cambridge University Press.

Fogel, R.W. and S.L. Engerman. 1974. Time on the Cross: The Economics of American Negro Slavery. Boston: Little, Brown.

Fogel, R.W., S.L. Engerman, R. Floud, R. Friedman, R.A. Margo, K. Sokoloff, R.H. Stecke1, T.J. Trussel1, G. Villaflor, and K.W. Wachter. 1983.

Secular Changs in American and British Stature and Nutrition. Journal of

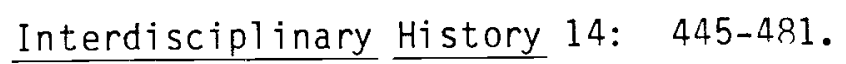

Fogel, R.W., S.L. Engerman, and J. Trusse11. 1982. Exploring the Uses of Data on Height: The Analysis of Long-Term Trends in Nutrition, Labor Welfare, and Labor Productivity. Social Science History 6: 401-42.1. Friedman, G.C. 1982. The Heights of Slaves in Trinidad. Social Science

History 6: $482-515$.

Frisancho, A.R. 1978. Nutritional Influences on Human Growth and

Retardation. Yearbook of Physical Anthropology 21: 174-191. Genovese, E.D. 1974. Roll Jourdan, Roll: The World the Slaves Made. New York: Pantheon.

Gray, L.C. 1933. History of Agriculture in the Southern United States to 1860,2 vols. Washington: Carnegie Institution. Habicht, J.P., R. Martorell, C. Yarbrough, R.M. Malina, and R.E. Klein. 1974. Height and Weight Standards for Preschool Children: How Relevant are Ethnic Differences in Growth Potential? Lancet April 6: 611-615. Healy, M.J.R. 1962. The Effect of Age-Grouping on the Distribution of a Measurement Affected by Growth. American Journal of Physical Anthropology 20: $49-50$.

Higman, B.W. 1984. Slave Populations of the British Caribbean, 1807-1834. Baltimore: Johns Hopkins. 
Hurley, L.S. 1980. Developmental Nutrition. Englewood Cliffs: Prentice$\mathrm{Ha} 11$.

Hytten, F.E. 1981. Nutrition in Relation to Fetal Growth. Pp. 57-62 in F. Andre Van Assche and W.R. Robertson, eds., Fetal Growth Retardation. Edinburgh: Churchill Livingstone.

Hytten, F.E. and I. Leitch. 1971. The Physiology of Human Pregnancy. 0xford: Blackwell.

Jelliffe, E.F.P. 1968. Low Birth-weight and Malarial Infection of the Placenta. Bulletin of the World Health Organization 33: 69-78. Keys, A., J. Brozek, A. Henschel, 0. Mickelsen, and H.L. Taylor. 1950. The Biology of Human Starvation, 2 vols. Minneapolis: University of Minnesota.

Kiple, K.F. and V.H. Kiple. 1977. Slave Child Mortality: Some Nutritional Answers to a Perennial Puzzle. Journal of Social History 10: 284-309. Kiple, K.F. and V.H. King. 1981. Another Dimension to the Rlack niaspora: Diet, Disease, and Racism. Cambridge: Cambridge University. Knodel, J. and H. Kinter. 1977. The Impact of Breast Feeding Pattern on the Biometric Analysis of Infant Mortality. Demography 14: 391-409. Lechtig, A., H. Delgado, R.E. Lasky, R.E. Klein, P.L. Engle, C. Yarbrough, and J.P. Habicht. 1975. Maternal Nutrition and Fetal Growth in Developing Societies. American Journal of Diseases in Childhood 129: 434-437. Malcolm, L.A. 1974. Ecological Factors Relating to Child Growth and Nutritional Status. Pp. 329-352 in A.F. Roche and F. Falkner, eds., Nutrition and Malnutrition: Identification and Measurement. New York: Plenum Press. 
Margo, R.A. and R.H. Steckel. 1982. The Heights of American Slaves: New Evidence on Slave Nutrition and Health. Social Science History 6: 516538.

- 1983. Heights of Native-Born Whites During the Antebellum

Period. Journal of Economic History. 43: 167-174.

Martorell, R. 1980. Interrelationships between Diet, Infectious Disease, and

Nutritional Status. Pp. 81-106 in L.S. Green and F.E. Johnston, eds.,

Social and Biological Predictors of Nutritional Status, Physical Growth,

and Neurological Development, New York: Academic Press.

Mata,L.J., J.J. Urrutia, and A. Lechtig. 1971. Infection and Nutrition of

Children of a Low Socioeconomic Rural Community. American Journal of

Clinical Nutrition 24: 245-259.

Metzer, J. 1974. Efficient Operation and Economies of Scale in the Ante-

Bellum Southern Plantation. Mimeo.

Naeye, R.L. and E.C. Peters. 1982. Working During Pregnancy: Effects on the

Fetus. Pediatrics 69: 724-727.

01 mstead, F.L. 1861. The Cotton Kingdom. New York: Alfred A. Knopf.

Owens, L.H. 1976. This Species of Property: Slave Life and Culture in the

0ld South. New York: Oxford University Press.

Phillips, U.B. 1918. American Negro Slavery. New York: D. Appleton and Co. Sandberg, L.G. and R.H. Steckel. 1980. Soldier, Soldier, What Made You frow

So Ta11? A Study of Height, Health, and Nutrition in Sweden, 1720-1881.

Economy and History 23: 91-105

Savitt, J.L. 1978. Medicine and Slavery: The Diseases and Health Care of

Blacks in Antebellum Virginia. Champaign: Iniversity of Illinois Press.

Scrimshaw, N.S. 1983. The Value of Contemporary Food and Nutrition Studies

for Historians. Journal of Interdisciplinary History 14: 529-534. 
Sokoloff, K.L. and G.C. Villaflor. 1982. The Early Achievement of Modern

Stature in America. Social Science History 6: 453-481.

Stampp, K.M. 1956. The Peculiar Institution. New York: Alfred A. Knopf.

Steckel, R.H. 1979a. Slave Height Profiles from Coastwise Manifests.

Explorations in Economic History 16: 363-380.

- 1979b. Slave Mortality: Analysis of Evidence from Plantation

Records. Social Science History 3: 86-114.

Steckel, R.H. 1982. The Fertility of American Slaves. Research in Economic

History 7: 239-286.

- 1983. Height and Per Capita Income. Historical Methods 16:

$1-7$.

- 1985a. The Health, Nutrition, and Mortality of American

Slaves from Childhood to Maturity. Mimeo.

- 1985b. Estimating Neonatal Mortality Rates From the Heights

of Children: The Case of American Slaves. Mimeo.

- 1985c. The Economics of U.S. Slave and Southern White

Fertility. New York: Garland Press.

Stein, Z., M. Susser, F. Saenger, and F. Marolla. 1975. Famine and Human

Development: The Dutch Hunger Winter of 1944-1945. New York: Oxford.

Sutch, R. 1975. The Treatment Received by American Slaves: A Critical

Review of the Evidence Presented in Time on the Cross. Explorations in

Economic History 12: $335-438$.

- 1976. The Care and Feeding of Slaves. Pp. 231-301 in P.A.

David, H.G. Gutman, R. Sutch, P. Temin, and G. Wright, eds., Reckoning

with Slavery. New York: Oxford University Press. 
Tafari, N., R.L. Naeye, and A. Gobezie. 1980. Effects of Maternal Indernutrition and Heavy Physical Work during Pregnancy on Birth Weight. British Journal of Obstetrics and Fynecology 87: 222-226. Tanner, J.M. 1962. Growth at Adolescence. Springfield, I11.: Thomas. - 1978. Fetus into Man: Physical Growth from Conception to

Maturity. London: Open Books.

- 1981. A History of the Study of Human Growth. Cambridge:

Cambridge University Press.

Tanner, J.M., R.H. Whitehouse, and M. Takaishi. 1966. Standards from Birth to Maturity for Height, Weight, Height Velocity, and Weight Velocity: British Children, Parts I and II. Archives of Disease in Childhood 41: 454-471 and 613-635.

Tanner, J.M., T. Hayashi, M.A. Preece, and N. Cameron. 1982. Increase in Length of Leg Relative to Trunks in Japanese Children and Adults from 1957 to 1977: Comparison with British and With Japanese Americans. Annals of Human Biology 9: 411-423.

United Nations. 1973. The Determinants and Consequences of Population

Trends, Vol. 1. Department of Economic and Social Affairs, Population Studies, No. 50. New York: United Nations. Wickes, I.G. 1953. A History of Infant Feeding, Parts I-V. Archives of Disease in Childhood 28: 151-158, 232-240, 332-340, 416-422, 495-502. Wray, J.D. 1978. Maternal Nutrition, Breast-Feeding and Infant Survival. Pp. 197-229 in W.H. Mosley, ed., Nutrition and Human Reproduction. New York: Plenum Press. 